\title{
Documentare la memoria storica. Linguaggi digitali per la gestione del patrimonio archeologico
}

Sabrina Acquaviva

\section{Abstract}

II contributo descrive i primi risultati di una ricerca finalizzata all'analisi delle possibili connessioni e interazioni tra dati di natura diversa (grafici e alfanumerici) e gli output delle operazioni di rilievo (nuvole di punti e modelli poligonali) all'interno di sistemi informativi tridimensionali, al fine di strutturare processi sistematizzati di documentazione e gestione dei contesti archeologici.

La creazione di un database inerente alle ville romane del territorio vesuviano, particolarmente ricco di resti archeologici, si pone come base per le successive sperimentazioni in ambiente tridimensionale spaziale (GIS 3D), dove il dato acquisito attraverso il rilievo diviene il supporto visivo a cui 'connettere' tutte le informazioni utili alla conoscenza del bene. Tale ricerca è focalizzata più nello specifico su di un singolo caso campione, la villa rustica romana di Caius Olius Ampliatus ricadente nel quartiere di Ponticelli (Napoli).

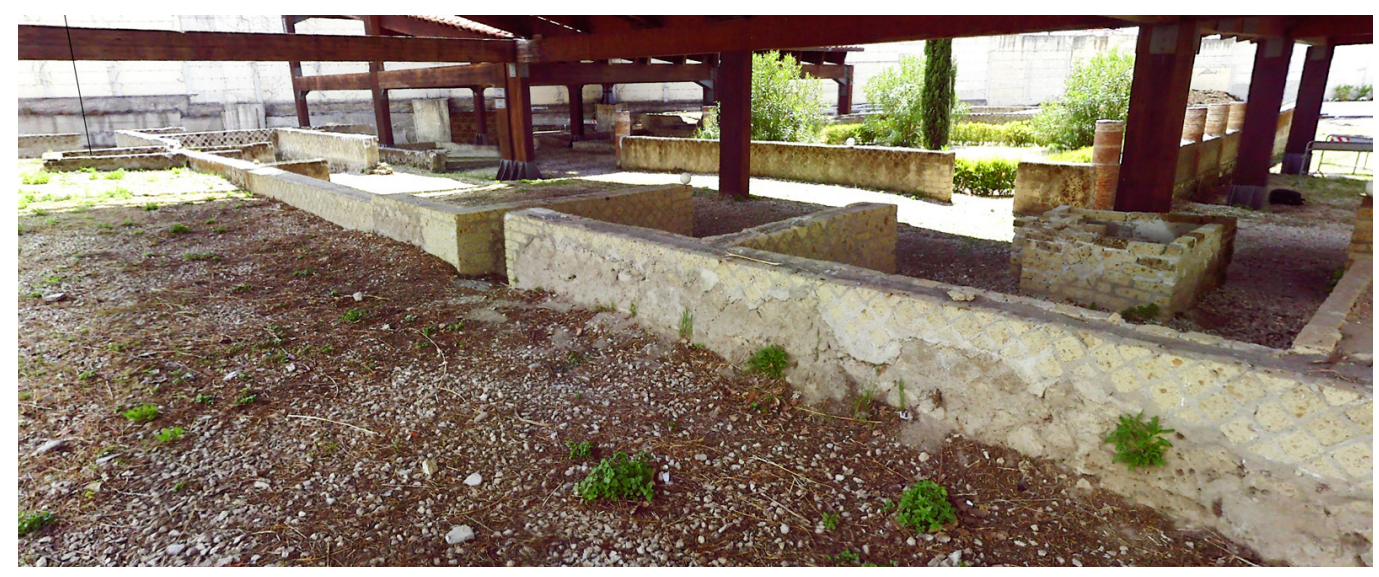




\section{Introduzione}

Documentare, gestire e tutelare il patrimonio archeologico si configura come un processo articolato che richiede approcci multidisciplinari la cui finalità è comprendere il significato dell'oggetto indagato nella sua complessità. Tali manufatti costituiscono testimonianze di un passato molto spesso celato, un insieme di tracce e di linguaggi antichi che si sono stratificati nel corso dei secoli. Il loro studio rende possibile non solo colmare la distanza con tale passato ma anche riscoprire gli eventi e le trasformazioni che ne hanno contrassegnato l'evoluzione, ampliando e diffondendo la conoscenza del bene e la sua memoria storica.

È evidente però come la lettura e l'analisi di questi contesti, esistenti e storicamente stratificati, comporti grandi criticità dovute alla loro natura frammentaria e fragile, soprattutto in relazione alla quantità di informazioni insita negli stessi. Inoltre, essi spesso rappresentano l'unica fonte documentaria concreta, che ha la necessità di essere indagata e interpretata secondo diverse chiavi di lettura al fine di poter estrapolare sempre nuovi dati, sfruttando a pieno il loro potenziale informativo.

La ricerca in campo archeologico si avvale del continuo sviluppo delle tecnologie digitali attraverso cui è possibile instaurare connessioni e mettere in relazione dati di natura diversa, rendendone più intuitiva la loro gestione e divulgazione tramite nuovi linguaggi digitali, per i quali il disegno e l'immagine visiva costituiscono gli elementi basilari per una comunicazione efficace.

Tali tecnologie hanno mutato sia le metodologie di acquisizione e rappresentazione della realtà che la qualità dei dati raccolti. La possibilità di creare repliche digitali di contesti reali, coadiuvando le fasi di scavo e/o di studio, ha permesso di instaurare una relazione diretta tra l'oggetto e il suo clone virtuale, portando profonde trasformazioni nella lettura stessa del dato. II modello reality-based diviene un elemento interattivo e dinamico di studio, attraverso il quale è possibile validare, o confutare, ipotesi costruttive ed evolutive di tali manufatti e, allo stesso tempo, costituisce la base per la costruzione di nuove strategie di gestione e archiviazione dei dati.

In tale ambito si inserisce il presente contributo che mira a descrivere i primi sviluppi di una ricerca condotta presso il Dipartimento di Architettura dell'Università di Napoli Federico II. Tali tematiche sono portate avanti attraverso processi operativi e metodologici applicati allo studio delle ville rustiche romane disseminate nel territorio vesuviano. Tra queste si è scelto come modello di indagine la villa romana di Ponticelli (Napoli), una delle poche ville rustiche ritrovate sul versante nord-occidentale del Vesuvio (fig. I).

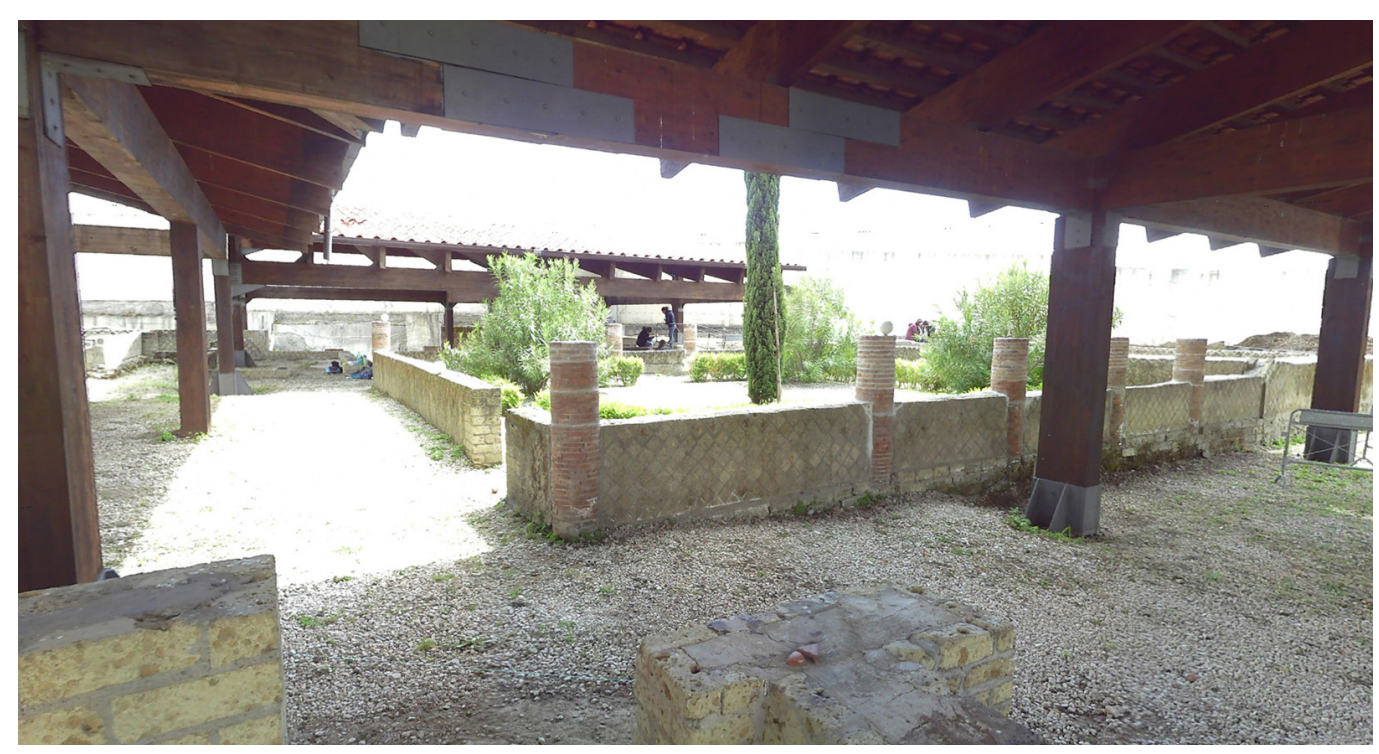




\section{Sistemi informativi in archeologia}

Ogni operazione archeologica, anche se reiterata sullo stesso manufatto, genera sempre nuove informazioni a seconda dell'obiettivo dell'indagine. Ciò nel tempo ha comportato la creazione di un ingente mole di dati, eterogenei e frammentari. L'opportunità di sistematizzare tali output, attraverso la creazione di banche dati, ha fatto sì che i sistemi GIS (Geographic Information System) divenissero di fondamentale ausilio per i lavori di ricerca in ambito archeologico. $\grave{E}$ indubbio che questi sistemi costituiscano una pratica oramai ampiamente consolidata, ma la possibilità di raccogliere in un unico workspace la conoscenza storica, la configurazione spaziale, il rapporto con il contesto e la descrizione diacronica delle parti, sia a scala territoriale che del singolo reperto, rendono questi applicativi ampiamente utilizzati all'interno del panorama archeologico e dei beni culturali [Forte 2002].

Lo sviluppo delle nuove tecnologie digitali ha potenziato anche tali sistemi, offrendo la possibilità di far interagire dinamicamente e mettere in relazione un'ampia tipologia di dati, agevolando il dialogo tra le diverse metodologie di indagine. Sono note le potenzialità date dall'integrazione degli output ottenuti dal processamento dei dataset_acquisiti tramite fotogrammetria e/o laser scanner allinterno di sistemi GIS [Malinverni 20 I9, pp. 3 I-39]. Ciò ha permesso di ottenere un dato accurato non solo dal punto di vista metrico e visivo ma anche spaziale, archiviato direttamente nel sistema, sempre interrogabile e soggetto a possibili nuove interpretazioni, soprattutto in quelle situazioni dove essi rappresentano gli unici dati disponibili ancora esistenti [D'Andrea, Bosco 2019, pp. 425-430]. E noto però che se da un lato tali sistemi GIS riescono a gestire e a ottimizzare i dati bidimensionali dall'altro presentano alcune lacune per quanto concerne il campo tridimensionale. Le ricerche più recenti stanno indirizzando i loro focus verso la sperimentazione di sistemi che siano in grado di gestire i modelli matematici e geometrici all'interno di contesti geospaziali, connettendoli con la documentazione storica e d'archivio. L'implementazione di software e la creazione di piattaforme ad hoc in grado di gestire il dato 3D ha permesso la sperimentazione di nuovi approcci metodologici, come ad esempio l'analisi delle diverse unità stratigrafiche murarie lavorando sulla mesh fotogrammetrica [Trizio et al. 2019, pp. 48-80]. In tal modo il modello diviene un elemento su cui poter interagire, associare informazioni e compiere analisi complesse.

Un'ulteriore fattore da tener presente è il livello di dettaglio della rappresentazione tridimensionale in ambiente GIS. Tali sistemi se si adattano alla rappresentazione del patrimonio architettonico, non consentono di ricreare la complessità delle forme archeologiche. In tal caso il modello semplificato, coadiuvato dalle informazioni archiviate, diviene uno strumento utile per i processi interpretativi archeologici [Landeschi 20 I8, pp. 17-32], demandando ad altri applicativi la replica fotorealistica della realtà [Ferdani et al. 2020, pp. |29-|43].

Per sopperire a tale mancanza nella modellazione tridimensionale, le sperimentazioni attuali puntano all'individuazione di una metodologia che permetta di far dialogare gli strumenti di modellazione informativa (HBIM) e i sistemi informativi territoriali (GIS3D), anche attraverso la correlazione e l'integrazione dei database [Garagnani et al. 2020, pp. | 81 - | 88; Scianna et al. 2020, pp. 231-252].

\section{Database delle ville rustiche vesuviane}

La prima fase del progetto ha avuto l'obiettivo di raccogliere e archiviare le informazioni storiche, morfologiche, fisiche e descrittive relative alle ville rustiche romane [I] dell'area vesuviana.

II processo è stato gestito attraverso il software ArcGIS di Esri, in grado di archiviare, gestire e rappresentare dati spaziali. Per ogni villa, attraverso layer puntuali, sono stati registrati: localizzazione e tipologia architettonica, quadro storico, tipologia costruttiva, stato di conservazione, accessibilità, allegati fotografici e documentari. Tali dati, sistematizzati in 
Fig. 2. Localizzazione e schedatura delle ville rustiche romane vesuviane.

Fig. 3.Villa romana di Caius Olius Ampliatus (ArcGis Pro)
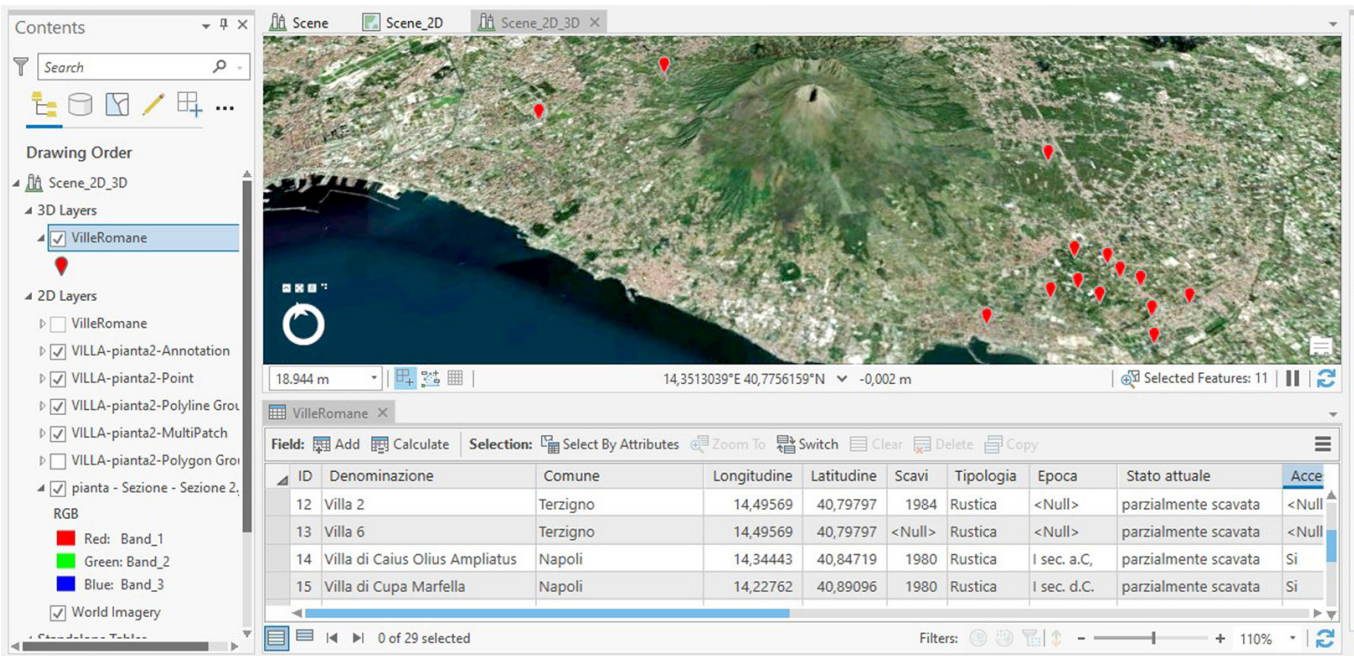

un database sempre implementabile, costituiscono le fondamenta per le successive analisi, fornendo un apporto conoscitivo non solo delle caratteristiche architettoniche dei singoli manufatti ma anche delle peculiarità storiche e geografiche (figg. 2, 3).

La fase successiva ha interessato l'approfondimento di un singolo caso campione, la villa romana di Ponticelli. Lo studio è stato coadiuvato da un rilievo integrato effettuato grazie all'ausilio delle moderne tecnologie digitali, quali scansioni laser e acquisizioni fotogrammetriche. II modello tridimensionale generato si è configurato quale una fonte di informazioni capace di arricchire il database precedentemente costruito, prefigurando allo stesso tempo un modello matematico utile per le successive analisi e sperimentazioni in ambiente tridimensionale.

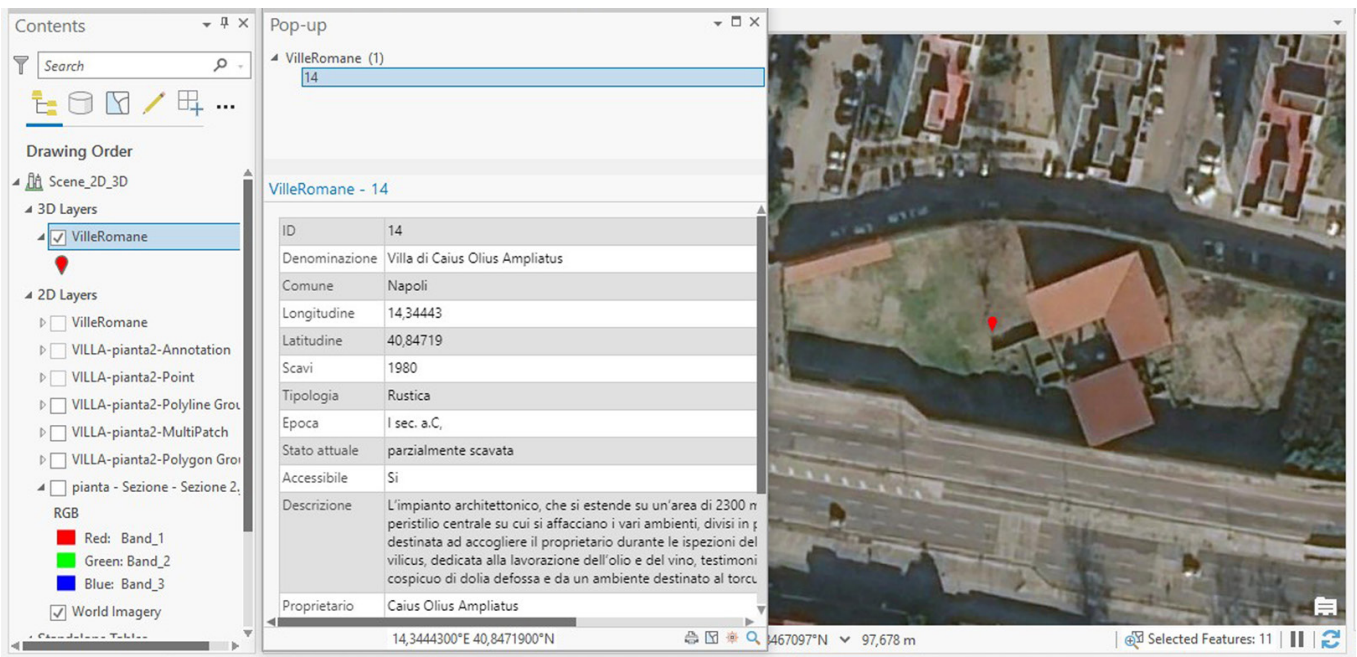

\section{Caso studio: La Villa Romana di Ponticelli}

La Villa romana di Caius Olius Ampliatus è ubicata nel quartiere di Ponticelli, sul versante nord-occidentale del Vesuvio. Tale ambito deve la sua attuale conformazione morfologica alle alterazioni provocate dagli eventi vulcanici susseguitisi nel corso dei secoli e alla massiccia urbanizzazione avvenuta negli ultimi cinquant'anni. 
Fig. 4. Pavimentazione della pars urbana (sinistra centro), particolare della decorazione (destra) [Cascella, Vecchio 2014 37 . 52 , 38 nn. $53,54]$ $3,54]$
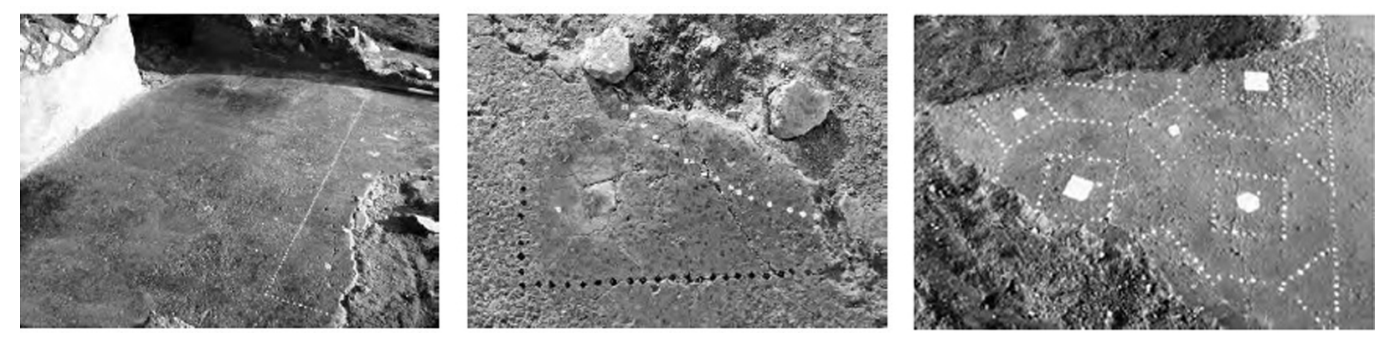

La villa è venuta alla luce grazie ai lavori per la realizzazione di un nuovo quartiere nell'area di Ponticelli, a seguito dell'emanazione della legge 2/9/80 per la ricostruzione post-terremoto. Si è trattato dunque di una scoperta fortuita avvenuta durante lo sbancamento dell'area, a seguito del quale sono stati rinvenuti reperti archeologici di varia natura. I resti, dopo una prima ricognizione, sono stati attribuiti a due ville, la prima, attribuita a Caius Olius Ampliatus [2], di epoca tardo-repubblicana mentre la seconda, a pochi passi dalla prima, tardo-traianea. Gli studi e la datazione di questo sito forniscono maggiori informazioni e dimostrano come anche su tale versante del Vesuvio il territorio fosse abitato già in epoca romana, permettendo di aggiungere un ulteriore tassello a quella storia in parte sepolta e sulla sua rioccupazione all'indomani della catastrofica eruzione del 79 d.C.
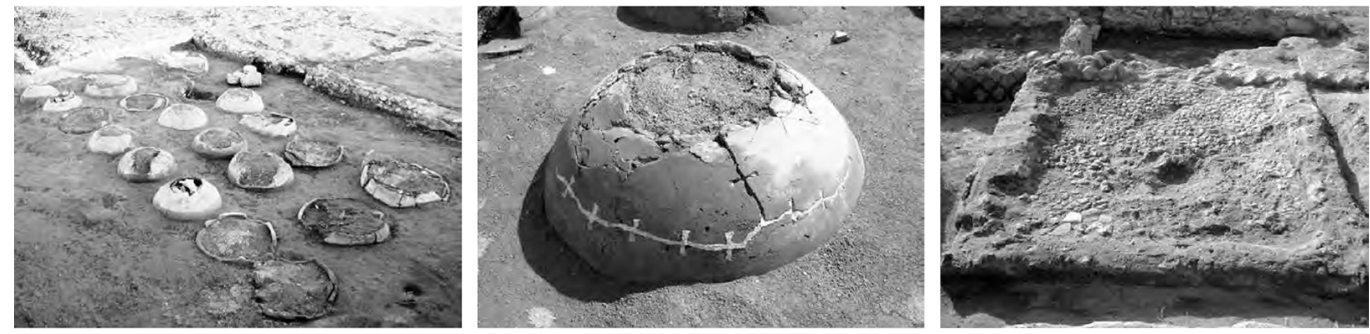

La struttura rientra nella cosiddette ville rustiche, insediamenti dediti alla produzione agricola e commerciale. L'impianto architettonico rispecchia i canoni della classica villa di tipo catoniano [3], sviluppandosi attorno a un piccolo peristilio centrale su cui si affacciano i vari ambienti, divisi in pars urbana e pars rustica. La prima destinata ad accogliere il proprietario durante le ispezioni del fundus (fig. 4), mentre la seconda, gestita dal vilicus, dedicata alla lavorazione dell'olio e del vino, circostanza confermata anche dalla presenza di un numero cospicuo di dolia e da un ambiente destinato al torcular vinario (fig. 5). I resti attualmente visibili rappresentano soltanto una porzione della villa. Essa deve il suo aspetto attuale al risultato di attente indagini archeologiche e di un successivo intervento di restauro che ne ha ricreato in parte l'articolazione degli ambienti (fig. 6), attraverso il rifacimento e il consolidamento di parte degli alzati dei muri [Cascella, Vecchio 20।4].
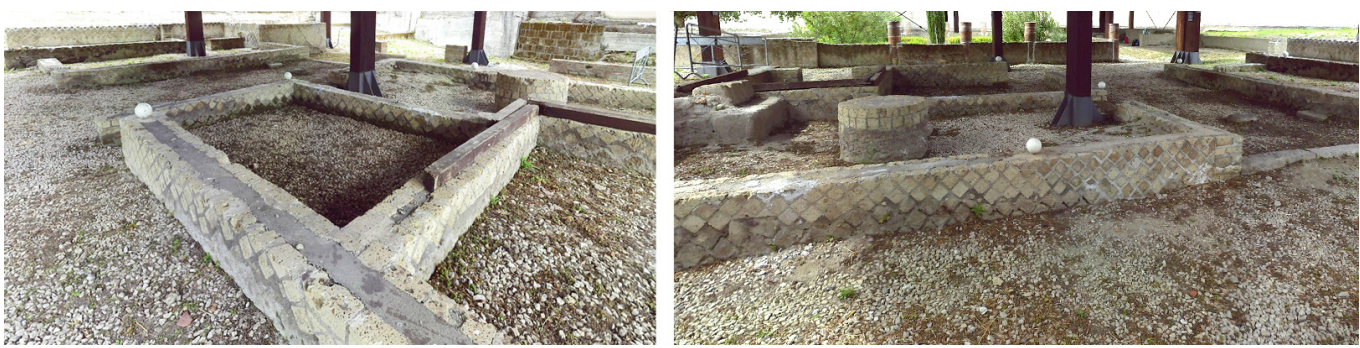

Fig. 6. Villa romana di
Caius Olius Ampliatus,

particolare degli ambienti della pars rustica. 
Fig. 7. Nuvola di punti della villa ottenuta dal processamento dei dati di rilievo.

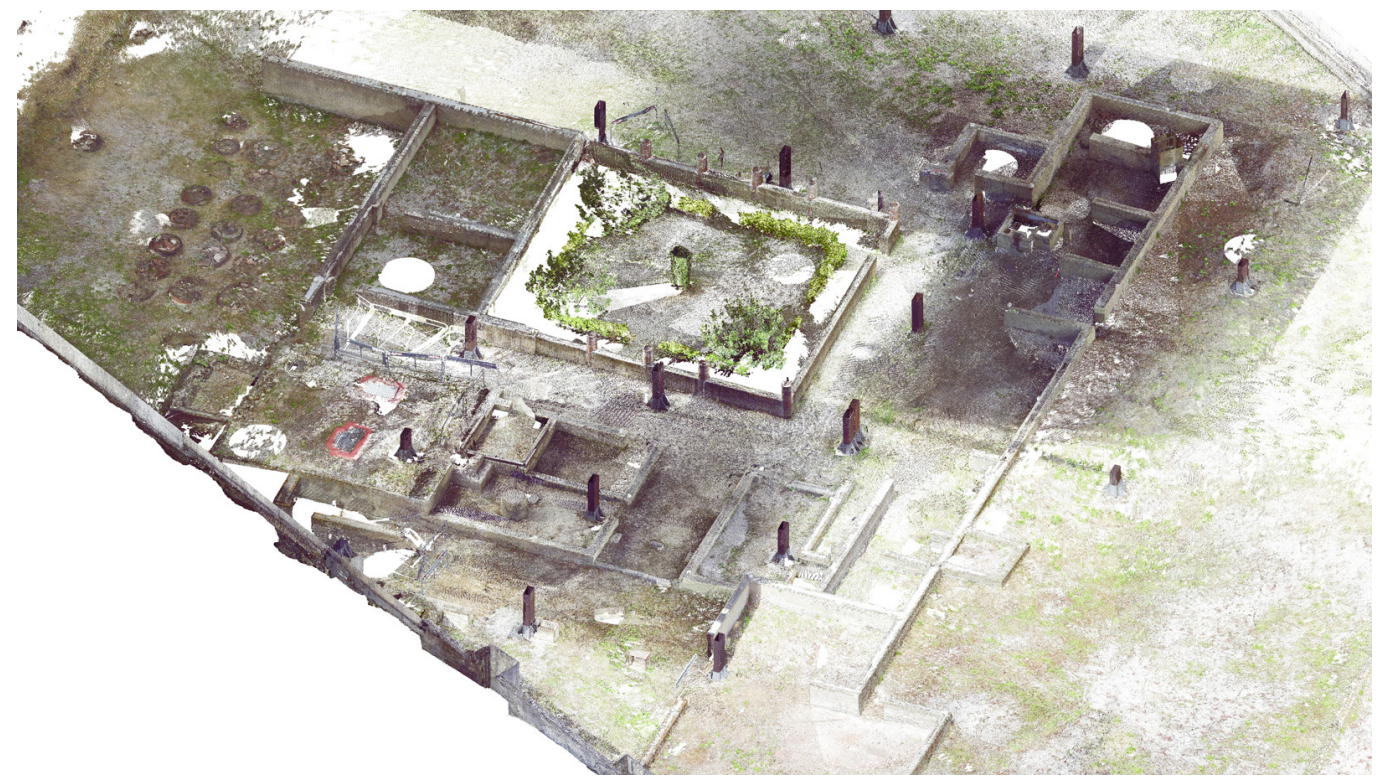

\section{Rilievo integrato per la conoscenza dei luoghi}

Lo studio e l'analisi delle fonti grafiche inerenti la Villa sono stati utilizzati non solo per comprendere l'articolazione del manufatto ma anche programmare la campagna di rilievo al fine di ottenere una documentazione aggiornata del sito.In particolare, in relazione alle peculiarità morfologiche e costruttive della Villa Romana di Ponticelli, si è scelto di effettuare un rilievo incentrato sull'utilizzo integrato delle metodologie reality-based, ottenendo un modello finale accurato metricamente e ottimale nella resa fotorealistica.

Nello specifico è stata eseguita una prima campagna di rilievo mediante l'utilizzo di un laser scanner Faro Focus 3D sl20, che permette di rilevare l'oggetto in tempi brevi con, in aggiunta, il dato colorimetrico. Sono state effettuate 27 scansioni per rilevare le evidenze architettoniche della villa ancora visibili. In seguito, un rilievo mediante tecniche Structure from Motion ha interessato i frammenti dei dolia presenti in situ. II dataset, acquisito con l'ausilio di una fotocamera Reflex Canon EOS I300D, è composto da 250 fotogrammi.

Poiché due ampie strutture proteggono parte della villa, generando particolari giochi di luce-ombre, che avrebbero potuto inficiare sui risultati del rilievo, si è ritenuto necessario operare in entrambi i casi in determinati momenti della giornata per raggiungere condizioni di illuminazione ottimali.

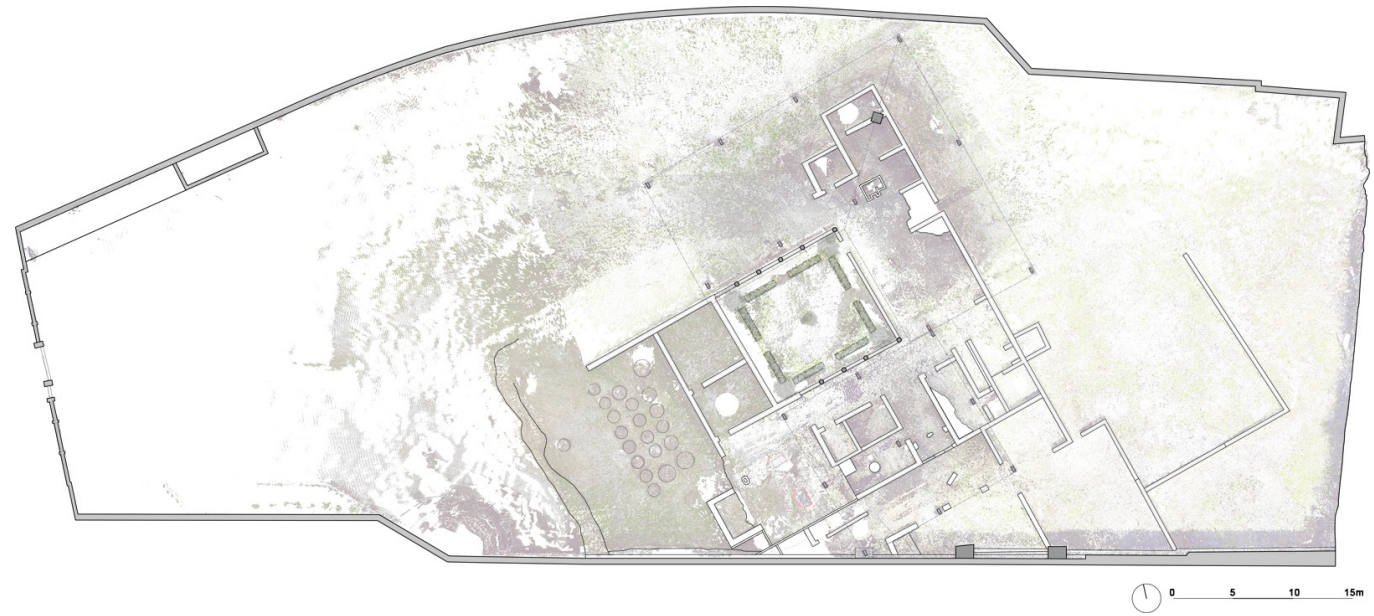


Fig. 9. Elaborazione dei dati. Particolare reticulatum.

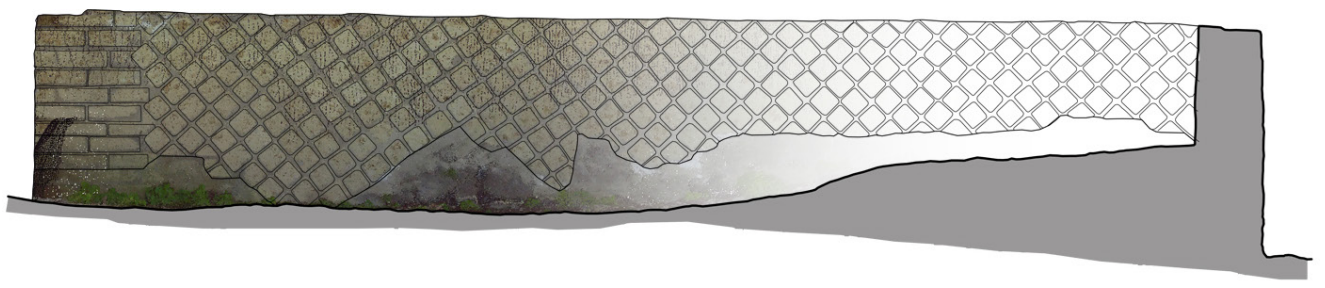

2 $3 m$

Le fasi successive di processamento e di registrazione dei dati hanno permesso di generare nuvole di punti rappresentative dell'intero bene. In particolare, le nuvole di punti provenienti dai rilievi laser sono state elaborate nel software proprietario FaroScene. II posizionamento nella scena di target sferici al momento dell'acquisizione ha facilitato la fase di processamento rendendola maggiormente speditiva. II dataset fotografico, invece, è stato elaborato attraverso il software RealityCapture, capace di estrarre la posizione e l'orientamento delle camere e generare una dense cloud. Entrambe le nuvole sono state poi sottoposte a un ulteriore fase di editing attraverso il filtraggio e il ricampionamento, per migliorare il dato 3D eliminando i punti estranei (noise) e non significativi ed evitare la presenza di elementi che avrebbero potuto creare disturbo nelle fasi successive di interpretazione e rappresentazione del dato.Infine, la nuvola laser è stata importata all'interno del software RealityCapture e integrata alla nuvola fotogrammetrica al fine di ottenere un dato completo e privo di eventuali zone d'ombra. La nuvola di punti integrata è diventata il supporto per l'elaborazione del modello poligonale e successiva texturizzazione (fig. 7). Generato il modello è stato utilizzato secondo due approcci differenti: estrazione delle ortofoto attraverso l'impostazione di piani di taglio sia orizzontali che verticali, importate in seguito all'interno di piattaforme GIS 2D e/o CAD (figg. 8-10) per la redazione di elaborati vettoriali bidimensionali; importazione e sperimentazione in ambiente GIS 3D per la creazione di un database tridimensionale (fig. $\mid \mathrm{I})$.

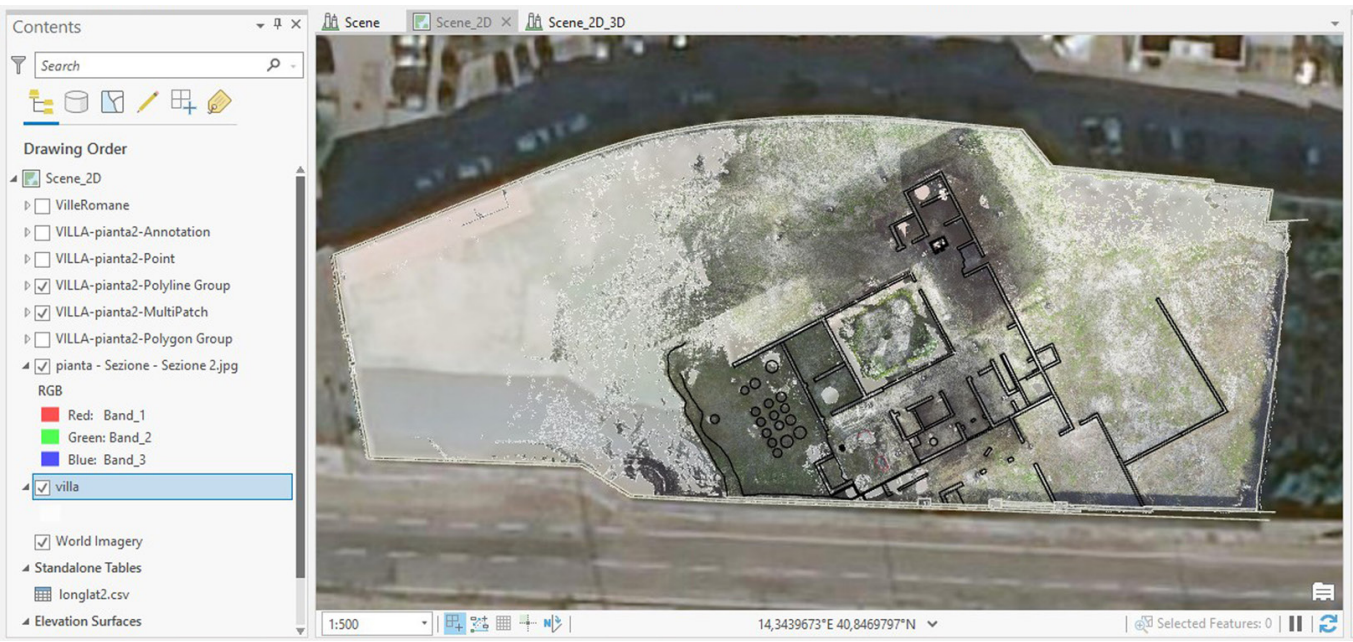

\section{Conclusioni}

La disamina della letteratura più recente ha mostrato come i processi di digitalizzazione e rappresentazione del patrimonio archeologico costituiscano un elemento di fondamentale importanza ai fini della sua conoscenza e tutela. Inoltre, la loro integrazione con sistemi GIS 
consente la creazione di banche dati che amplificano la possibilità di interazione e condivisione di tali informazioni.

La schedatura delle ville rustiche romane del territorio vesuviano attraverso l'archiviazione dei dati storici, tipologici e morfologici, ha agevolato le operazioni di confronto e di studio tra esse. II database così costruito, sempre implementabile, rappresenta sia uno strumento essenziale per portare avanti la ricerca scientifica che la base per la creazione di applicazioni webGIS utili alla fruizione e alla valorizzazione di tali beni. II successivo rilievo del singolo caso studio ha consentito di implementare il database informativo dei dati morfo-metrici estratti dalla nuvola di punti. Sviluppi futuri della ricerca puntano a indagare le modalità di archiviazione e integrazione di tale modello matematico in ambiente GIS.

L'approccio ipotizzato nel presente contributo rappresenta un esempio reiterabile, attraverso il quale è possibile creare una rete di connessioni informative tra la documentazione tradizionale e i nuovi linguaggi digitali al fine di ampliare la comprensione e l'interpretazione della complessità delle evidenze archeologiche.
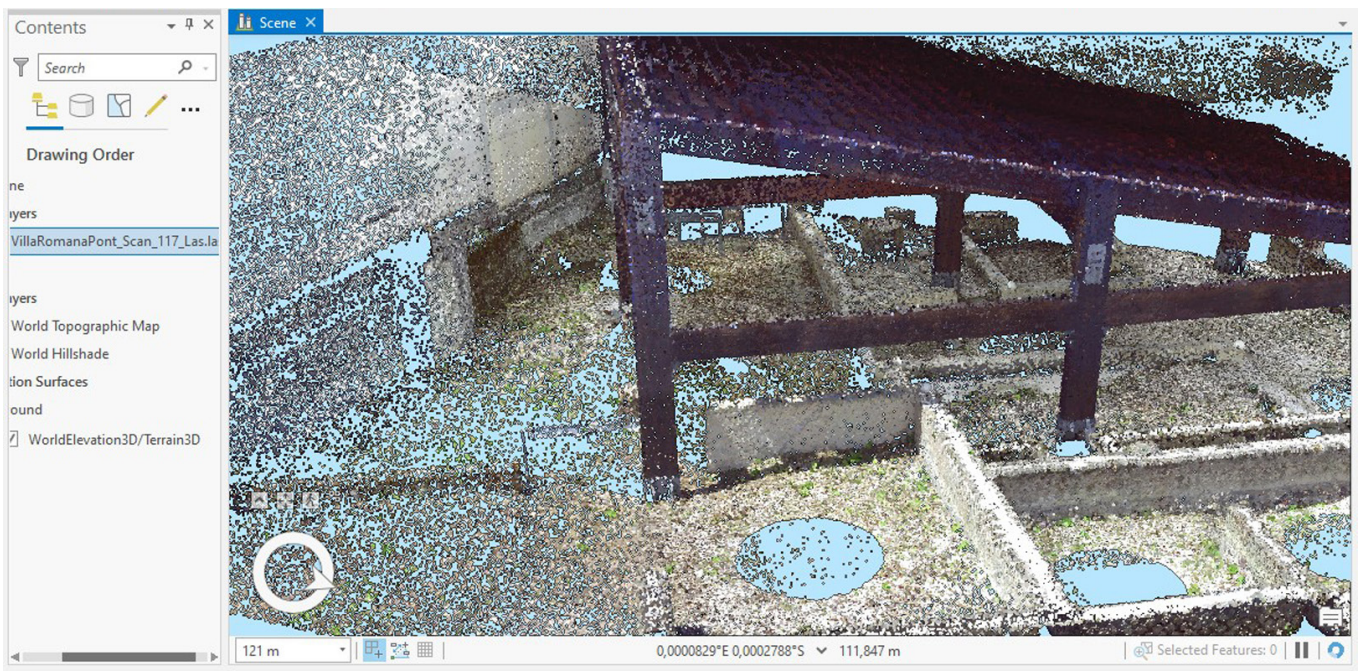

Note

[I] La villa rustica era considerata una vera e propria fattoria. A seconda della sua dimensione e della sua ubicazione poteva essere dotata, accanto alla pars rustica, di una piccola pars urbana.

[2] Fu ritrovato un signaculum bronzeo con l'incisione "C. Olius Ampliatus".

[3] Liber de agri cultura, M. P. Catone, II sec. a.C.

\section{Riferimenti bibliografici}

Cascella S., Vecchio G. (2014). La villa rustica di C. Olius Ampliatus. Suburbio sud-orientale di Napoli (Ponticelli). Oxford: British Archaeological Reports Oxford Ltd.

D'Andrea A., Bosco A. (2019). La documentazione grafica per lo studio dei beni archeologici attraverso la replica digitale 3D. In P. Belardi (a cura di). Riflessioni: l'arte del disegnolil disegno dell'arte, UID Unione Italiana Disegno. Atti del $41^{\circ}$ Convegno internazionale dei Docenti delle discipline della Rappresentazione. Perugia, 19-2I settembre 20 I9, pp. 425-430. Roma: Gangemi Editori.

Ferdani D. et al. (2020). 3D reconstruction and validation of historical background for immersive VR applications and games: The case study of the Forum of Augustus in Rome. In Journal of Cultural Heritage, vol. 43, pp. 129- I43. <https://doi.org/ 0 . I0 $16 /$. culher.2019.12.004> (consultato il 23 gennaio 2021).

Forte M. (2002). I sistemi informativi geografici in archeologia. Roma: MondoGis.

Garagnani S., Gaucci A. (2020). The ArchaeoBIM method and the role of digital models in archaeology. In Archeologia e Calcolatori, vol. XXXI.2, pp. I8I- 188. <https://doi.org/ | 0.19282/ac.31.2.2020.17> (consultato il 5 febbraio 202 I). 
Landeschi G. (20 I8). Rethinking GIS, three-dimensionality and space perception in archaeology. In World Archaeology, 5 I: I, pp. 17-32. < https://doi.org/ 1 0.1080/00438243.2018.1463171 > (consultato il 20 gennaio 2021).

Malinverni E. S. et al. (2019). Virtual museum enriched by GIS data to share science and culture. Church of Saint Stephen in Umm Ar-Rasas (Jordan). In Virtual Archaeology Review, vol. 10 (21), pp. 31-39. <https://doi.org/l0.4995/var.2019.II9|9> (consultato il 15 dicembre 2020).

Scianna A., Gaglio G. F., La Guardia M. (2020). HBIM data management in historical and archaeological buildings. In Archeologia e Calcolatori, vol. XXXI. I, pp. 23I-252. <https://doi.org/I 0.19282/ac.31.I.2020. I > (consultato il 5 febbraio 202 I).

Trizio I. et al. (2019). Photogrammetric survey and 3D GIS management of mesh in the integrated investigation of complex sites. The case study of the archaeological complex of the Terme diVespasiano at Cittaducale (RI), Italy. In C. Inglese, A. Ippolito (a cura di). Conservation, Restoration and Analysis of Architectural and Archaeological Heritage. Hershey: IGI Global, pp. 48-80. <https://doi.org/ | 0.40 I 8/978-I-5225-7555-9.ch003> (consultato il 7 gennaio 202I).

Autore

Sabrina Acquaviva, Università di Napoli “Federico II”, sabrina.acquaviva@unina.it

Per citare questo capitolo: Acquaviva Sabrina (2021). Documentare la memoria storica. Linguaggi digitali per la gestione del patrimonio archeologico/Documenting historical memory. Digital languages to manage the archaeological heritage. In Arena A., Arena M., Mediati D., Raffa P. (a cura di). Connettere. Un disegno per annodare e tessere. Linguaggi Distanze Tecnologie. Atti del $42^{\circ}$ Convegno Internazionale dei Docenti delle Discipline della Rappresentazione/Connecting. Drawing for weaving relationship. Languages Distances Technologies. Proceedings of the $42^{\text {th }}$ International Conference of Representation Disciplines Teachers. Milano: FrancoAngeli, pp. 19-36. 


\section{Documenting Historical Memory. Digital Languages to Manage the Archaeological Heritage}

Sabrina Acquaviva

Abstract

The paper describes the first results of a research aimed at analysing the possible connections and interactions between data of different nature (graphic and alphanumerics) and the outputs of survey operations (point clouds and polygonal models) within three-dimensional information systems, in order to structure systematic processes of documentation and management of archaeological contexts. The creation of a database concerning the Roman Villas of the Vesuvian territory, particularly full in archaeological remains, is the foundation for following experiments in three-dimensional space (3D GIS). The data acquired through the survey becomes the visual support which 'connect' all the information useful for the knowledge of the artefacts. This research is focused more specifically on a single case study, the Roman rustic villa of Caius Olius Ampliatus in the district of Ponticelli (Naples).

Keywords

Roman villa, archaeology of the architecture, GIS, digital survey, database.

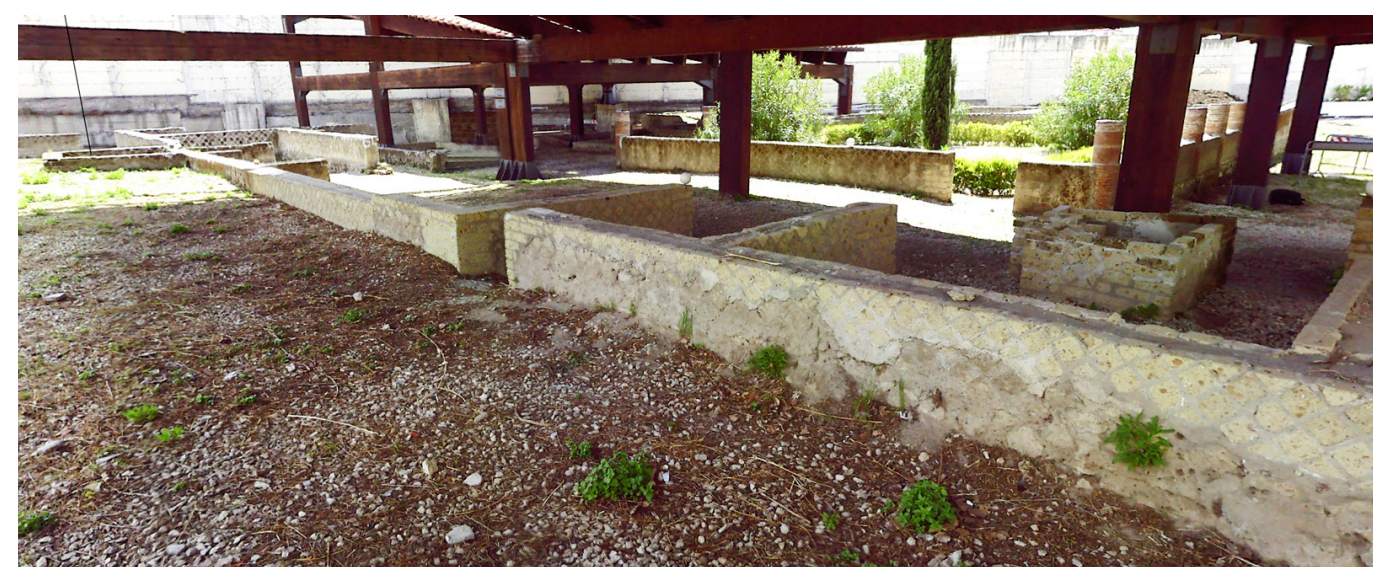




\section{Introduction}

Documenting, managing and preserving the archaeological heritage is an articulated process that requires multidisciplinary approaches whose purpose is to understand the meaning of the entire investigated object. These artifacts are evidence of a very often hidden past, a set of traces and ancient languages stratified over the centuries. Their study makes it possible not only to fill the gap with this past, but also to rediscover the events and transformations that have marked them evolution, spreading the knowledge of the asset and them historical memory. However, the reading and analysis of these existing and historically stratified contexts involve great critical issues due to their fragmented and fragile nature, especially in relation to their amount of information inherent. In addition, they often represent the only concrete documentary source, which needs to be investigated and interpreted according to different reading key in order to always extract new data, fully exploiting their information potential.

Research in the field of archaeology makes use of the continuous development of digital technologies. They allow to establish connections between data of a different nature, making their management and dissemination more intuitive through new digital languages, for which drawing and visual imaging are the basic elements for effective communication. These technologies have changed both the methods of acquisition and representation of reality and the quality of the data collected. The ability to create digital replicas of real contexts has made it possible to establish a direct relationship between the object and its virtual clone, assisting the excavation and / or study phases. So, it is possible make a new reading of the data itself. The reality-based model becomes an interactive and dynamic element of study, through which it is possible to validate, or confute, constructive and developmental hypotheses of such artifacts. At the same time, this model constitutes the basis for the construction of new strategies for the management and storage data.

In this field is included the present contribution that aims to describe the first developments of a research conducted at the Department of Architecture of the University of Naples Federico II. These topics are carried out through operational and methodological processes applied to the study of the Roman rustic villas scattered throughout the Vesuvian territory. Among these, the Roman villa of Ponticelli (Naples) was chosen as the model of investigation (fig. I), one of the few rustic villas found on the north-western side of Vesuvius.

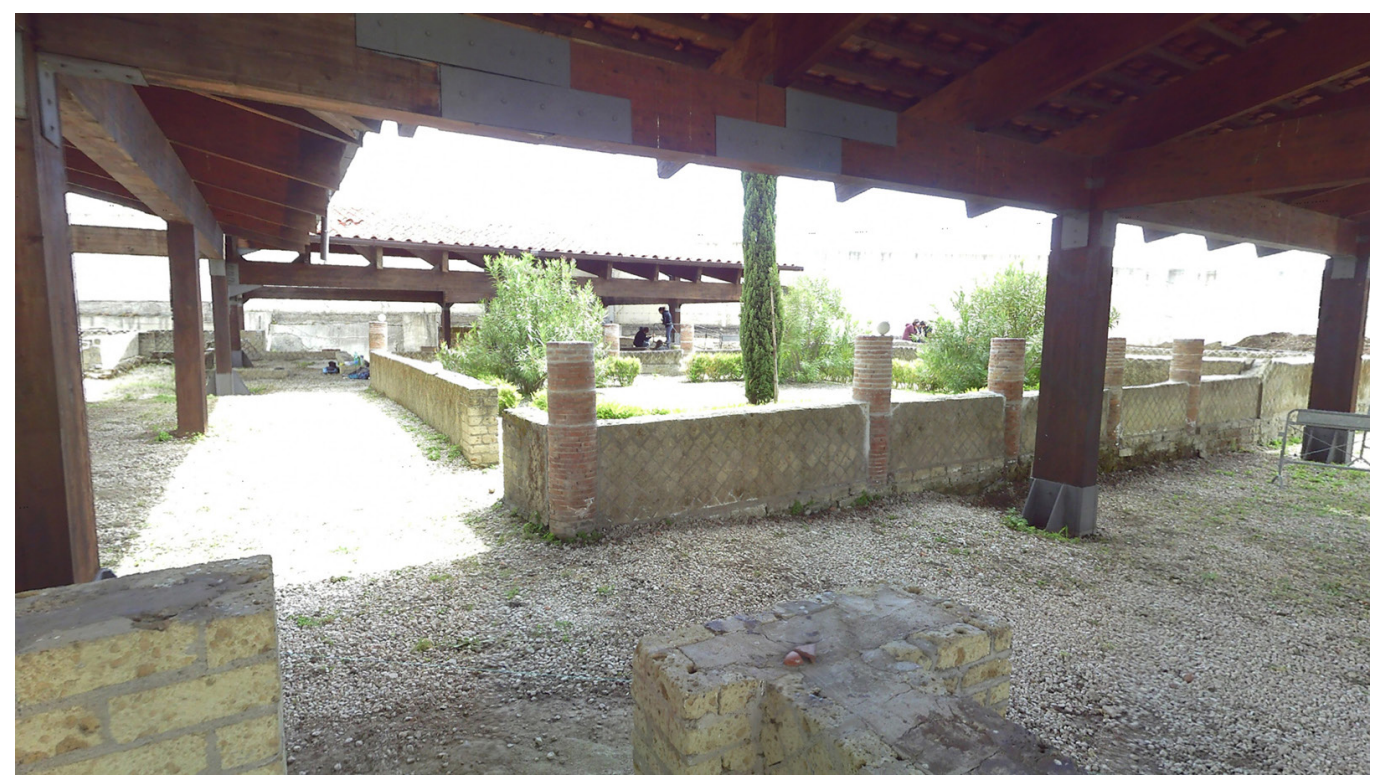




\section{Information systems in archaeology}

Each archaeological operation always generates new information depending on the aim of the investigation, even if repeated on the same artifact. Through time, this has led to the creation of a large amount of data, heterogeneous and fragmentary. The Geographic Information Systems are becoming of fundamental aid for the research work in the archaeological field, through the creation of databases. These systems constitute a well-established practice, but the possibility to gather in a single workspace the historical knowledge, the spatial configuration, the relationship with the context and the diachronic description of the parties make these applications widely used within the archaeological field and cultural heritage, both on a territorial scale and of the single find [Forte 2002]. The development of new digital technologies has also enhanced these systems, offering the possibility of dynamically interacting and relating a wide type of data, facilitating dialogue between the different methodologies of investigation. The potential given by the integration of the outputs obtained by the processing of datasets acquired by photogrammetry and/or laser scanner within GIS systems is well known [Malinverni 2019, pp. 31 -39]. This has allowed to obtain an accurate data not only from the metric and visual point of view but also from the spatial. This data is also stored directly in the system, always interrogated and subject to possible new interpretations, especially in those situations where they represent the only available data still existing [D'Andrea, Bosco 20 I9, pp. 425430]. It is known that the GIS systems manage the two-dimensional data, while they have some gaps in the three-dimensional field. The most recent research is focusing on the experimentation of systems that are able to manage mathematical and geometric models within geospatial contexts, connecting them with historical and archive documentation. The implementation of software and the creation of platforms able to manage the 3D data has allowed to experiment new methodological approaches, such as the analysis of the different stratigraphic units working on the photogrammetric mesh [Trizio et al. 2019, pp. 48-80]. In this way the model becomes an element on which to interact, associate information and carry out complex analyses.

A further factor to keep in mind is the level of detail of the three-dimensional representation in GIS environment. Although these systems are adapting to the representation of the Architectural Heritage, they do not allow to recreate the complexity of archaeological forms. In this case, the simplified model becomes a useful tool for archaeological interpretative processes, assisted by archived information, [Landeschi 2018, pp. 17-32], assigning to other applications the photorealistic replica of reality [Ferdani et al. 2020, pp. I29- I43]. To overcome this lack in three-dimensional modelling, current experiments aim at the identification of a methodology that allows the communication of information modelling tools (HBIM) and spatial information systems (GIS3D) through correlation and integration of databases. [Garagnani et al. 2020, pp. I 8 I - |88; Scianna et al. 2020, pp. 23 I-252].

\section{Database of rustic Vesuvian villas}

The aim of the first phase of the project was to collect and archive historical, morphological, physical and descriptive information relating to the Roman rustic villas [I] of the Vesuvian area.

The process was managed through Esri's Arcgis software, capable of archiving, managing and representing spatial data. The data recorded for each villa were: location, architectural typology, historical framework, construction typology, conservation status, accessibility, photographic and documentaries attachments. Such data are systematized in a database always implementable and constitute the foundations for the successive analyses, supplying a cognitive contribution not only of the architectonic characteristics of the single artefacts but also of them historical and geographic peculiarities (figs. 2, 3).

The next phase involved the deepening of a single sample case, the Roman villa of Ponticelli. The study was supported by an integrated survey carried out by modern digital 
Fig. 2. Location and registration of Roman Vesuvian rustic villas.

Fig. 3. Roman Villa of Caius Olius Ampliatus (Arcgis Pro).
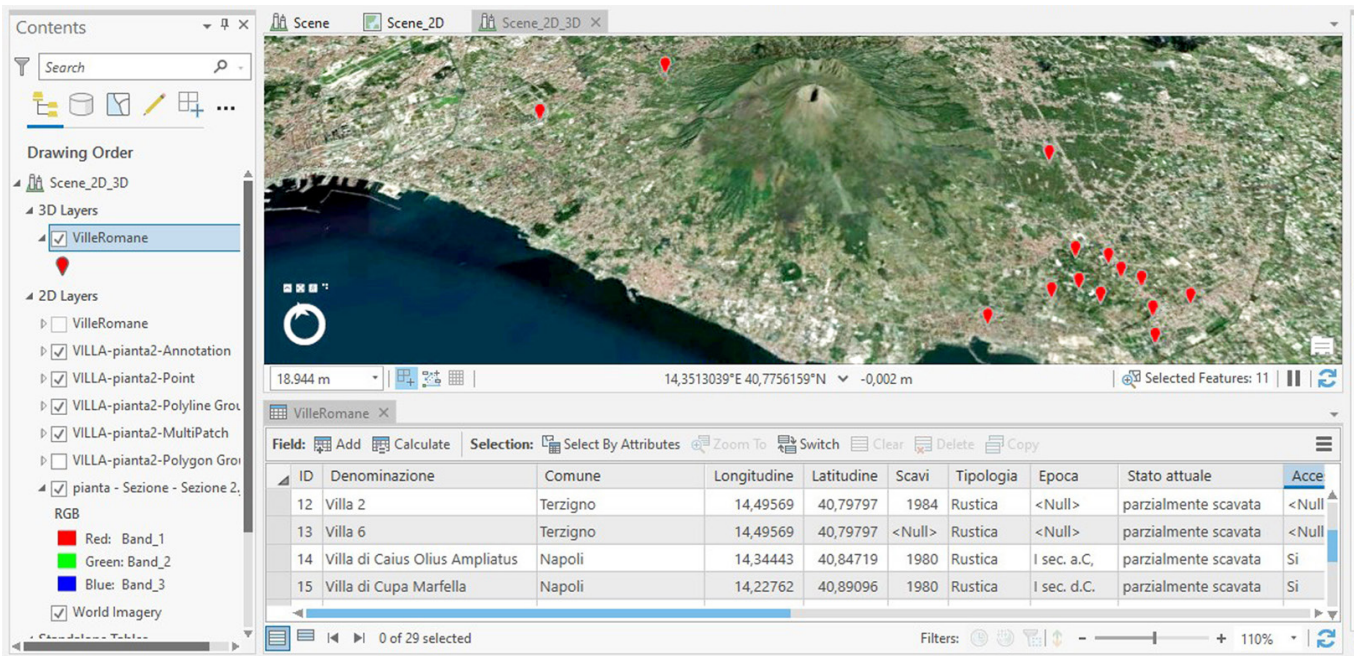

technologies, such as laser scans and photogrammetric acquisitions. The three-dimensional model represents a source of information ables to enrich the database previously built and at the same time a mathematical model useful for subsequent analysis and experimentation in a three-dimensional environment.

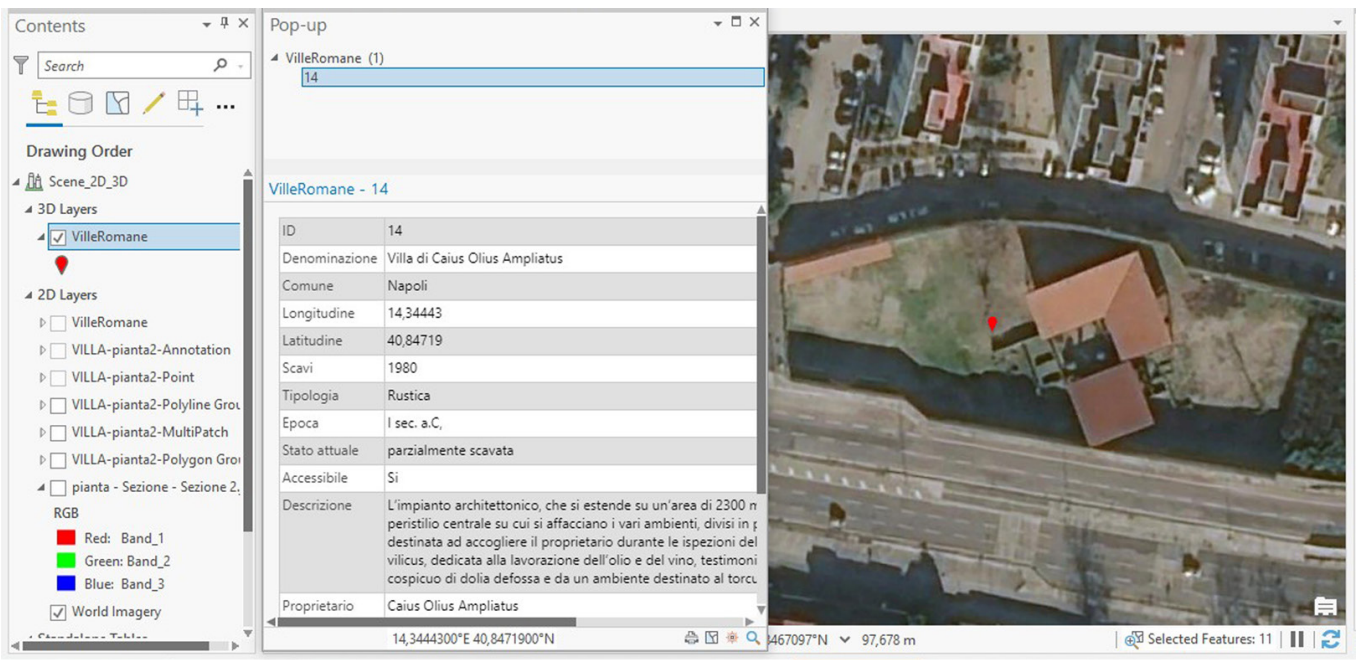

\section{Case study: The Roman Villa of Ponticelli}

The Roman Villa of Caius Olius Ampliatus is in the district of Ponticelli, on the north-western side of Vesuvius. This area owes its current morphological conformation to the alterations caused by the volcanic events over the centuries and the massive urbanization occurred in the last fifty years.

The villa discovered by the works for the construction of a new district in Ponticelli, according to law 219/80 for post-earthquake reconstruction. Therefore, it was a fortuitous discovery occurred during the excavation of the area, following which were found archaeological finds. After a first reconnaissance, the remains were attributed to two villas, the first belonging to the late Republican era, attributed to Caius Olius Ampliatus [2], while the second late Trajan, a few steps from the first. 
Fig. 4. Floor of the pars urbana (left, center) decorative detail (right) ( 37 n. 52 , p. 38 nn $3,54]$.
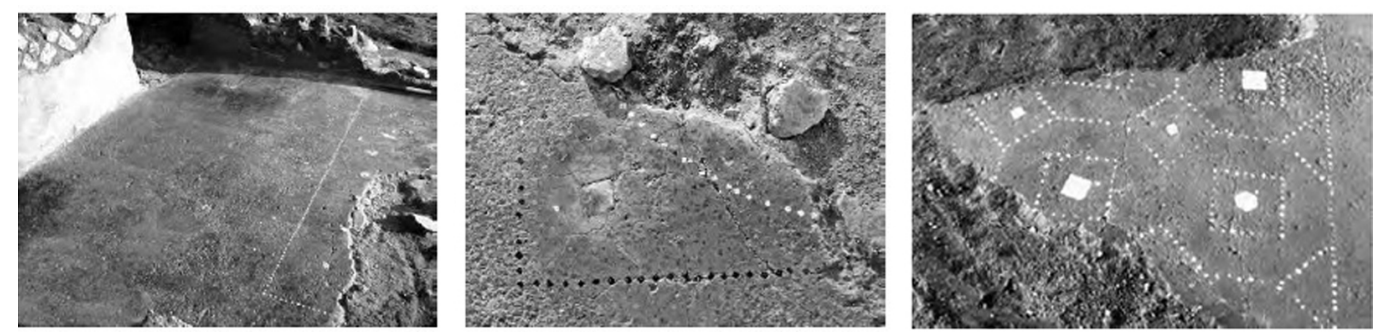

The studies and the dating of this site provide more information and demonstrate that this territory was inhabited already in Roman times. This allowed to add a further piece to that story partly buried and on its reoccupation in the aftermath of the catastrophic eruption of 79 AD.

The structure is part of the so-called rustic villas, settlements dedicated to agricultural and commercial production. The architectural layout reflects the canons of the classic Catonian villa [3]. It develops around a small central peristyle on which overlook the various environments, divided into pars urbana and pars rustica. The first pars were used to accommodate the owner during fundus inspections (fig. 4). Instead, the second was managed by vilicus for the processing of oil and wine, a circumstance confirmed also by the
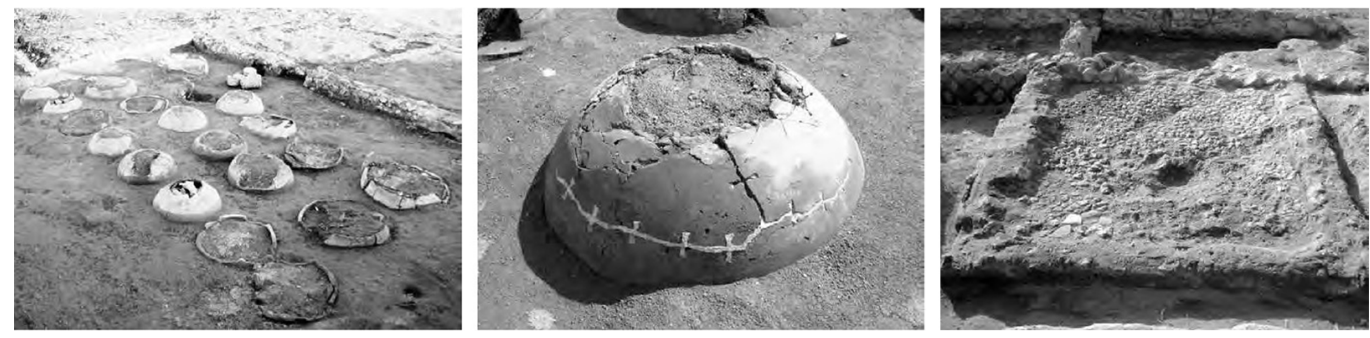

presence of a conspicuous number of dolia and by an environment destined to torcular vinario (fig. 5). The remains currently visible represent only a portion of the villa. Its current appearance is the result of careful archaeological investigations and a subsequent restoration that has partially recreated the articulation of the environments (fig. 6), through the reconstruction and consolidation of part of the walls [Cascella,Vecchio 20I4].

\section{Integrated survey for knowledge of places}

The study and analysis of the graphic sources related to the Villa were used not only to understand the articulation of the artifact but also to plan the survey campaign in order
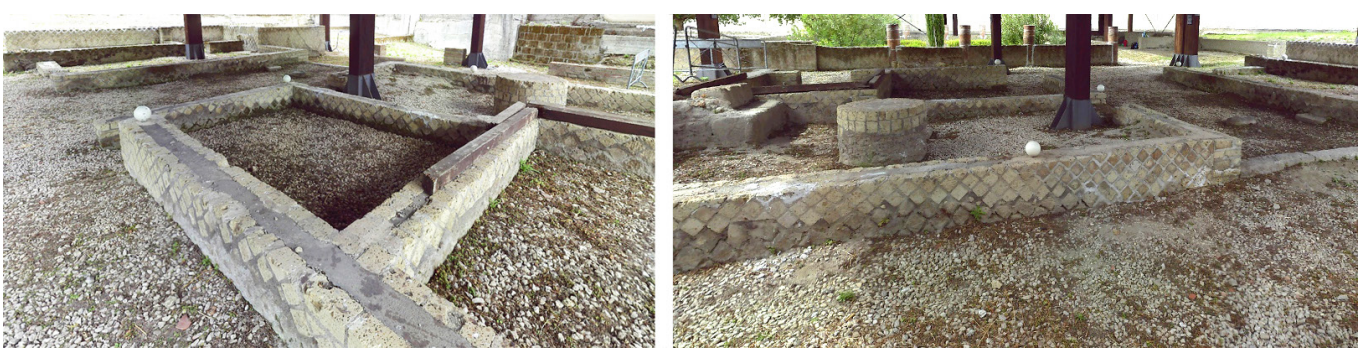
Fig. 7. Point cloud of the villa obtained by processing of the survey data.

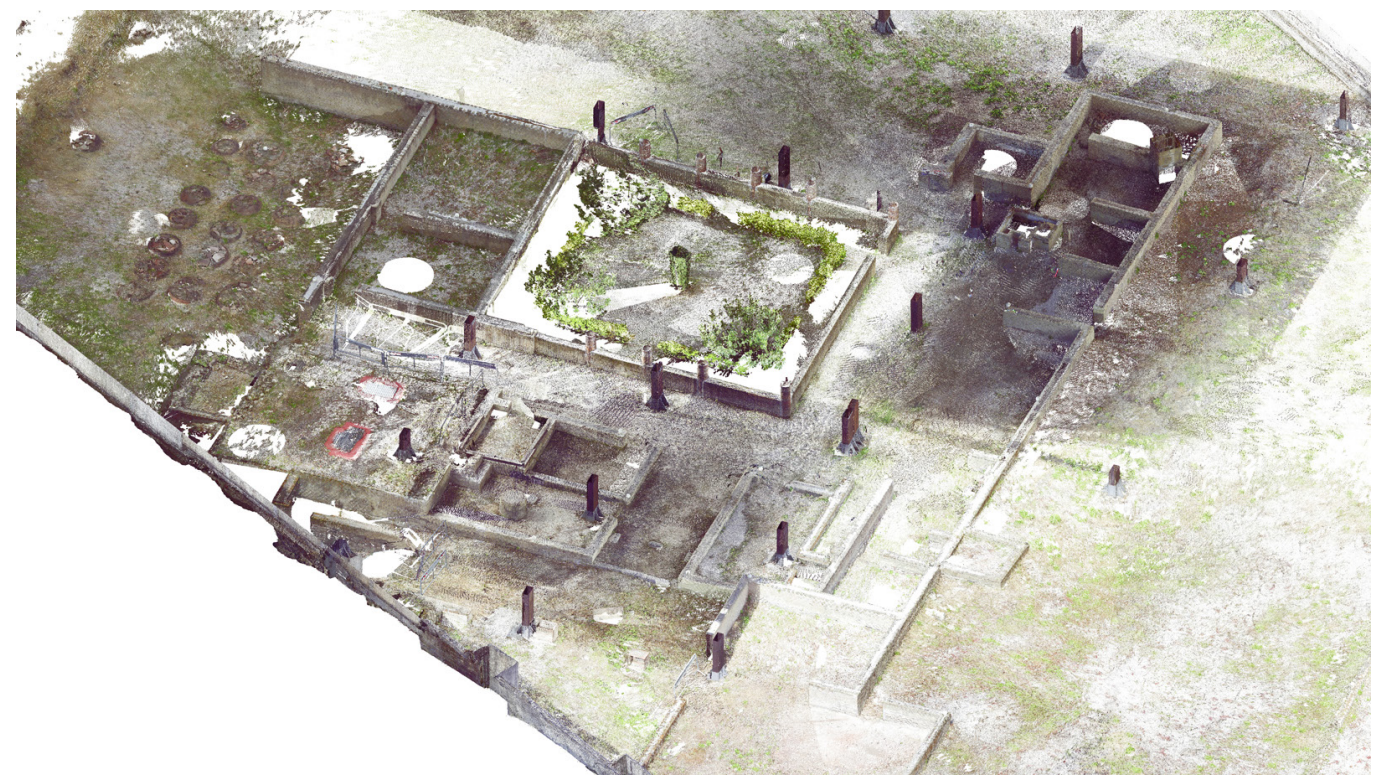

to obtain an updated documentation of the site. In particular, in relation to the morphological and constructive peculiarities of the Villa Romana in Ponticelli, it was decided to carry out a survey focused on the integrated use of reality-based methodologies, obtaining a final model accurate metrically and optimal in photorealistic yield.

Specifically, a first survey campaign was carried out using a laser scanner Faro Focus 3D s 120, which allows to detect the object in a short time with, in addition, the colorimetric data. 27 scans were made to detect the architectural evidence of the villa still visible. Subsequently, a survey using Structure from Motion techniques involved fragments of dolia found in situ. The dataset consists of 250 frames, acquired by Canon EOS I300D SLR camera. It was necessary to operate in both cases in specific times of the day to achieve optimal lighting conditions. In fact, two large structures protect part of the villa generate particular effects of light-shadows, which could have affected the survey results. The successive phases of processing and recording of the data have allowed to generate point clouds representative of the entire asset. In particular, the point clouds from the laser surveys were processed in the proprietary software FaroScene. The position of spherical target in the scene at the time of the acquisition facilitated the processing phase, making it faster. Instead, the photographic dataset has been elaborated through the software

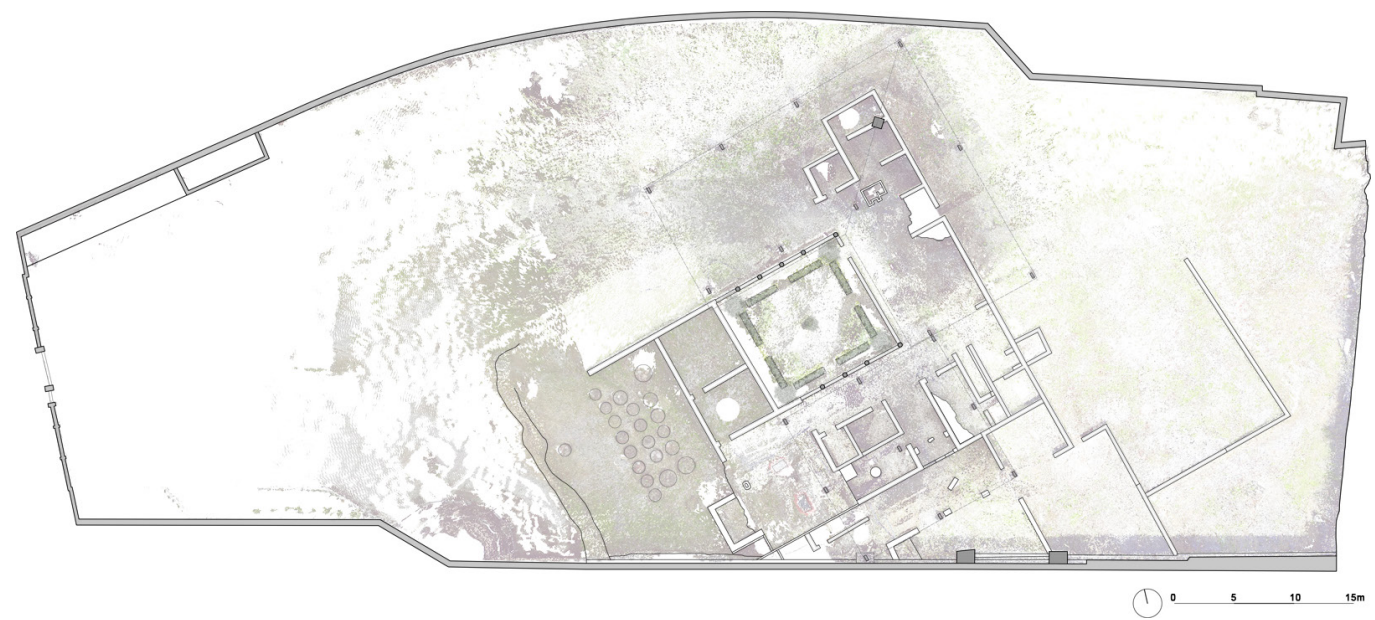


Fig. 9. Data processing. Detail of the structure in opus reticulatum.

Fig. 10. Orthophoto and plan of the Roman villa of Ponticelli in GIS environment.

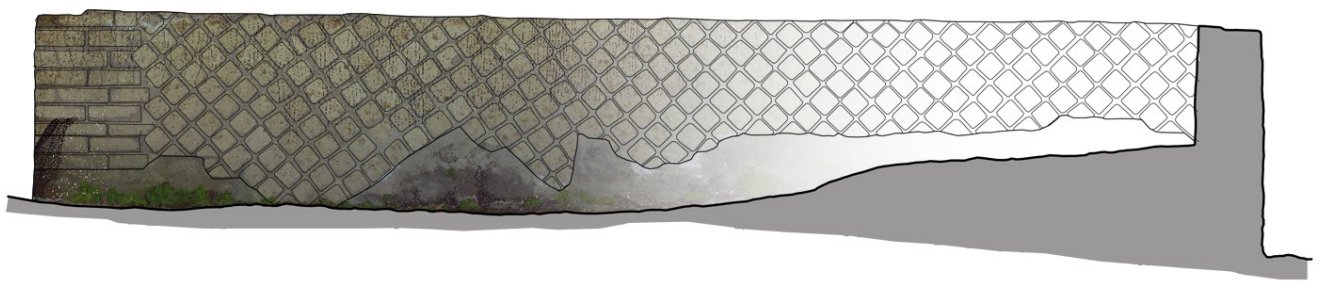

2

$3 m$

RealityCapture, able to extract the position and the orientation of the cameras and to generate a dense cloud. Then both clouds were subjected to a further editing phase through filtering and resampling to improve 3D data, eliminating extraneous (noise) and not significant points. So, it possible to avoid the presence of elements that could have created disturbance in the subsequent stages of interpretation and representation of the data. Finally, the laser cloud was imported into the RealityCapture software and integrated to the photogrammetric cloud in order to obtain a complete data. The integrated point cloud has become the support for the elaboration of the polygonal and textured model (fig. 7). This model has been used according to two different approaches: extraction of orthophotos through the setting of both horizontal and vertical cutting planes, imported later in 2D CAD and/or GIS platforms (figs. 8-10) for the preparation of two-dimensional vector elaborations; import and experimentation in 3D GIS environment for the creation of a three-dimensional database (fig. I I).

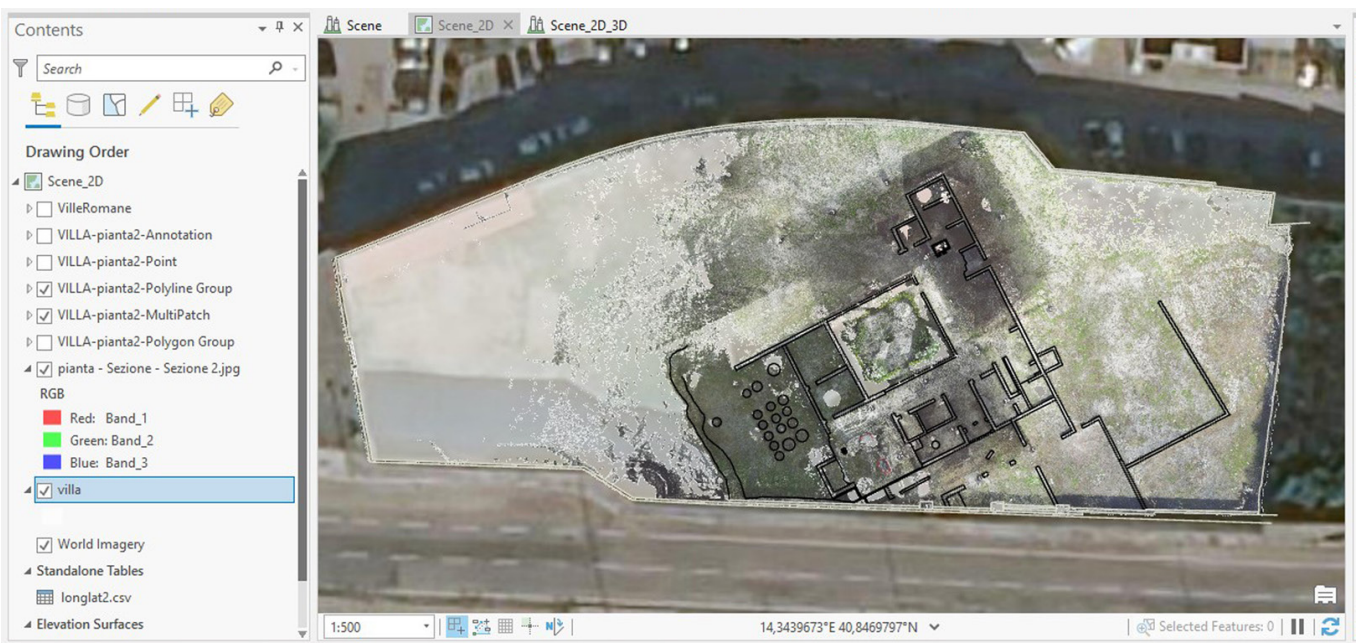

\section{Conclusions}

The examination of the most recent literature has shown that the processes of digitalization and representation of archaeological heritage are an element of fundamental importance for its knowledge and protection. In addition, their integration with GIS systems allows the creation of databases that amplify the possibility of interaction and sharing of such information. Through the archiving of historical, typological and morphological data, the filing of the Roman rustic villas of the vesuvian territory has facilitated the operations 
of comparison and study between them. This database is both an essential tool for carrying out scientific research and the basis for the creation of webGIS applications useful for the use and enhancement of these assets. It can always be implemented. The subsequent survey of the single sample case allowed to implement the informative database of morphometric data extracted from the point cloud. Future research developments aim to investigate how to archive and integrate this mathematical model into the GIS environment. The approach envisaged in this contribution is a repeatable example. Through this approach it is possible to create a network of informative connections between traditional documentation and new digital languages in order to broaden the understanding and interpretation of the complexity of archaeological evidence.
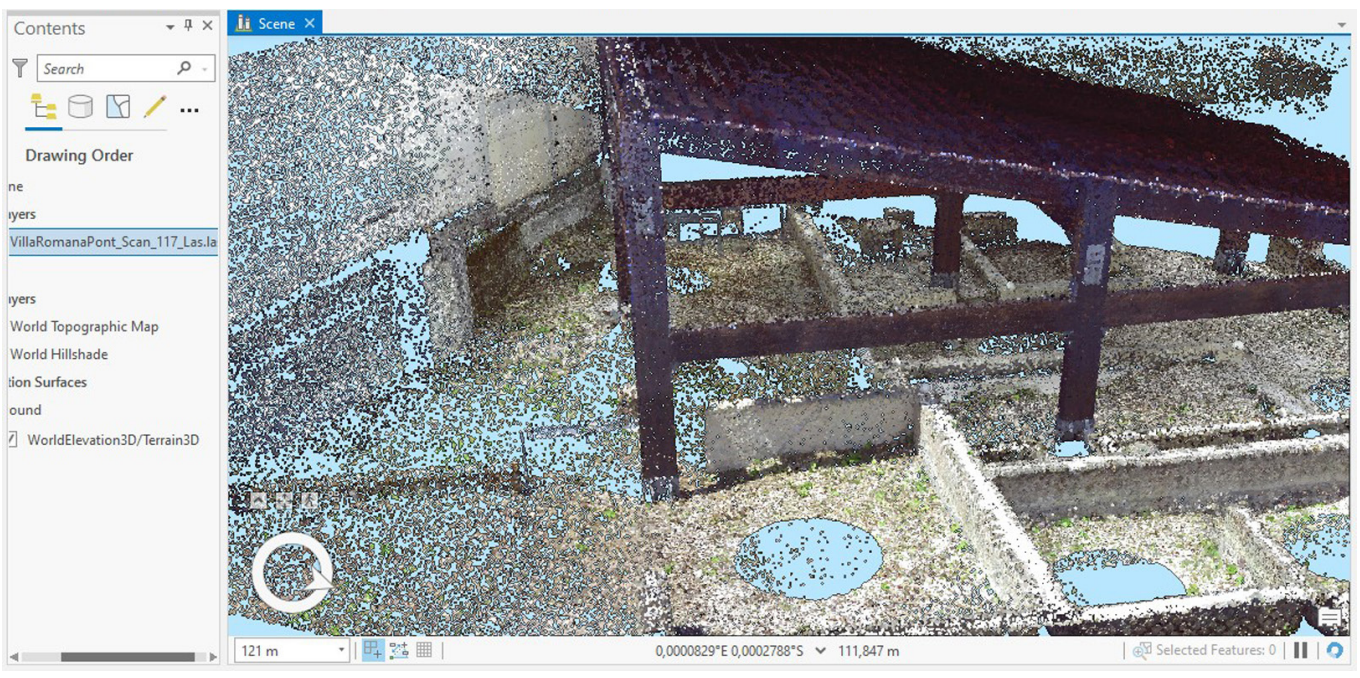

Notes

[I] The rustic villa was considered a real farm. Depending on its size and location, it could be equipped with a small urban pars, next to the pars rustica.

[2] A bronze signaculum was found with the engraving "C. Olius Ampliatus".

[3] Liber de agri cultura, M. P. Catone, II sec. B.C.

\section{References}

Cascella S., Vecchio G. (2014). La villa rustica di C. Olius Ampliatus. Suburbio sud-orientale di Napoli (Ponticelli). Oxford: British Archaeological Reports Oxford Ltd.

D'Andrea A., Bosco A. (2019). La documentazione grafica per lo studio dei beni archeologici attraverso la replica digitale 3D. In P. Belardi (a cura di). Riflessioni: l'arte del disegnolil disegno dell'arte, UID Unione Italiana Disegno. Atti del $41^{\circ}$ Convegno internazionale dei Docenti delle discipline della Rappresentazione. Perugia, 19-2I settembre 20 I9, pp. 425-430. Roma: Gangemi Editori.

Ferdani D. et al. (2020). 3D reconstruction and validation of historical background for immersive VR applications and games: The case study of the Forum of Augustus in Rome. In Journal of Cultural Heritage, vol. 43, pp. I29- I43. <https://doi.org/ I 0. I016/1. culher.2019.12.004> (accessed 2021, January 23).

Forte M. (2002). I sistemi informativi geografici in archeologia. Roma: MondoGis.

Garagnani S., Gaucci A. (2020). The ArchaeoBIM method and the role of digital models in archaeology. In Archeologia e Calcolatori, vol. XXXI.2, pp. I8I-188. <https://doi.org/I0.19282/ac.31.2.2020.17> (accessed 2021, February 5). 
Landeschi G. (20 I 8). Rethinking GIS, three-dimensionality and space perception in archaeology. In World Archaeology, 5 I: I, pp. 17-32. < https://doi.org//0.1080/00438243.2018.1463171> (accessed 2021, January 20).

Malinverni E. S. et al. (2019). Virtual museum enriched by GIS data to share science and culture. Church of Saint Stephen in Umm Ar-Rasas (Jordan). In Virtual Archaeology Review, vol. I0 (2I), pp. 31-39. <https://doi.org/I0.4995/var.2019.I I9|9> (accessed 2020, 15 December).

Scianna A., Gaglio G. F., La Guardia M. (2020). HBIM data management in historical and archaeological buildings. In Archeologia e Calcolatori, vol. XXXI.I, pp. 23I-252. <https://doi.org/I 0.19282/ac.31.1.2020.1 I> (accessed 2021, February 5).

Trizio I. et al. (2019). Photogrammetric survey and 3D GIS management of mesh in the integrated investigation of complex sites. The case study of the archaeological complex of the Terme diVespasiano at Cittaducale (RI), Italy. In C. Inglese, A. Ippolito (a cura di). Conservation, Restoration and Analysis of Architectural and Archaeological Heritage. Hershey: IGl Global, pp. 48-80. <https://doi.org/ | 0.40 18/978-I-5225-7555-9.ch003> (accessed 2021, January 20).

Author

Sabrina Acquaviva, Università di Napoli “Federico II”, sabrina.acquaviva@unina.it

To cite this chapter: Acquaviva Sabrina (202I). Documentare la memoria storica. Linguaggi digitali per la gestione del patrimonio archeologico/ Documenting historical memory. Digital languages to manage the archaeological heritage In Arena A Arena M Mediati D Raffa P. (a cura di). Connettere. Un disegno per annodare e tessere. Linguaggi Distanze Tecnologie. Atti del $42^{\circ}$ Convegno Internazionale dei Docenti delle Discipline della Rappresentazione/Connecting. Drawing for weaving relationship. Languages Distances Technologies. Proceedings of the $42^{\text {th }}$ International Conference of Representation Disciplines Teachers. Milano: FrancoAngeli, pp. 19-36. 